\title{
Why are the French so different from the Germans? Underpricing of IPOs on the Euro New Markets
}

\author{
Marc Goergen $^{\mathrm{a}}$, Arif Khurshed ${ }^{\mathrm{b}, *}$, Luc Renneboog ${ }^{\mathrm{c}}$ \\ a Cardiff Business School and European Corporate Governance Institute (ECGI), Cardiff University, \\ Aberconway Building, Colum Drive, Cardiff, CF10 3EU, United Kingdom \\ ${ }^{\mathrm{b}}$ Manchester Business School, University of Manchester, Oxford Road, Manchester M15 6PB, United Kingdom \\ ${ }^{\mathrm{c}}$ Tilburg University and ECGI, PO Box 90153, 5000 LE Tilburg, The Netherlands
}

\section{A R T I C L E I N F O}

\section{JEL classification:}

G14

G24

Keywords:

IPOs

Underpricing

Venture capital

High technology

European New Markets

Lock-up agreements

\begin{abstract}
A B S T R A C T
We study the underpricing of firms listed on the two largest EuroNM stock exchanges, the Neuer Markt of Germany and the Nouveau Marché of France. We find that the high underpricing in these two markets - contrary to the evidence on the US - is not driven by insiders' selling behaviour. However, the large underpricing is caused by the high degree of riskiness of the issuing firms and by the partial adjustment phenomenon of offer prices to compensate institutional investors for the truthful revelation of their demand for the shares. For France, lock-up agreements act as substitutes to underpricing, but not so for Germany. We also explore the reasons for the large difference in underpricing between the German and the French IPOs: German firms are more underpriced because they are riskier, have larger price revisions, have less stringent VC lock-up contracts, and go public mostly during the hot issue period when the general level of underpricing in all IPO markets is substantially higher.
\end{abstract}

(c) 2009 Elsevier Inc. All rights reserved.

\section{Introduction}

In an initial public offering (IPO), a firm offers its shares to the public for the first time via a listing on a stock exchange. One of the interesting features of IPOs is that shares usually trade on the first day of listing at a price which is higher than the offer price. This anomaly is termed underpricing. Traditionally, for the stock markets of the developed world, the level of underpricing averaged between 10 and $15 \%$. However, the recent literature on firms that were floated during the dot com bubble years of 1999 and 2000 documents that underpricing reached astronomical levels of more than $70 \%$ in the US markets (Ljungqvist \& Wilhelm, 2003). Further, the IPOs of internet firms yielded first-day returns exceeding $96 \%$ during this period (Ofek \& Richardson, 2003). Relatively high underpricing was also observed on a number of European markets (Ritter, 2003). In particular, Goergen, Khurshed, McCahery, and Renneboog (2003) find that during the period of 1996-2000, IPOs on the newly formed stock markets of Europe were underpriced by more than $30 \%$ on their first day of trading.

\footnotetext{
* Corresponding author at: Division of Accounting and Finance, Manchester Business School, University of Manchester, Manchester M13 9PL, UK.

E-mail addresses: GoergenM@cardiff.ac.uk (M. Goergen), Arif.khurshed@mbs.ac.uk (A. Khurshed), Luc.Renneboog@uvt.nl (L. Renneboog).
}

This paper focuses on the reasons for the high underpricing of firms listed on the new stock markets of Europe (EuroNMs). Studying underpricing of IPOs on the EuroNMs is interesting for at least two reasons. First, being new stock markets, largely developed along the lines of NASDAQ, the EuroNMs are likely to provide interesting insights into their listing activity and post-IPO performance. Second, IPOs on the EuroNMs are different from those on the other, established primary markets of their country: the majority of these firms are relatively young, are from high tech industries, have a shorter trading record, and face stricter listing requirements such as lock-up agreements. ${ }^{1}$ They are also frequently venture-capital financed and often have over-allotment options.

The IPOs on the German and French EuroNMs, ${ }^{2}$ which are the focus of this study, attracted more than 90\% of all the EuroNM IPOs. Our results show underpricing in the German Neuer Markt of about 53\% during the period of 1997-2000. This is about five times the past level of underpricing reported by Ljungqvist (1997)

\footnotetext{
${ }^{1}$ Lock-up agreements are agreements which prevent the incumbent shareholders from selling further shares during a certain period after the IPO. See Goergen et al. (2006) for an overview of the regulation on lock-ups across Europe and the US.

2 The first EuroNM was created in 1996 in France (the Nouveau Marché) and later encompassed its German (Neuer Markt), Dutch (NMAX), Belgian (EuroNM Belgium) and Italian (Nuovo Mercato) equivalents, which were all placed under the umbrella of EuroNM.
} 
for Germany. In comparison, during the period of 1996-2000, the underpricing in the French Nouveau Marché amounted to 21\%, about twice the past level (Derrien \& Womack, 2003). Interestingly, we find that neither the selling behaviour of insiders in the IPO nor the involvement of venture capitalists has any impact on underpricing. In addition, price revisions during the offer process occur more frequently in Germany and are larger than those in France. This suggests that the German investors were more forthcoming with information about the potential demand for shares enabling the investment banks to set more accurate prices and/or were overoptimistic about their national IPO market. For France, lock-up agreements are a substitute for underpricing. The more stringent the lock-up, the smaller is the level of underpricing. In some firms, the underwriters are also shareholders in the firms they are taking public. For Germany, this leads to higher underpricing whereas for France it has the opposite effect.

Finally, we study some of the reasons behind the large differences in underpricing between the two markets. We find that German IPOs are more underpriced because they are riskier, provide a larger compensation for the truthful revelation of information by potential investors, have less stringent VC lock-up contracts and mostly come to the market during the hot issue period when the average underpricing in all IPO markets is substantially higher.

The rest of the paper is organised as follows. Section 2 briefly discusses the creation (and demise) of the French and German EuroNM markets and compares the characteristics of the two markets. Section 3 reviews the current literature on underpricing on the European New Markets. Section 4 then discusses the determinants of underpricing and formulates the hypotheses, while Section 5 specifies the data sources and describes the sample. Section 6 documents the underpricing in the two EuroNMs and relates it to the IPO characteristics. Section 7 discusses the results and Section 8 concludes.

\section{The rise and fall of the EuroNMs}

The European New Markets (EuroNMs) were launched in $1996 / 1997$ in order to facilitate the financing of innovative companies with a potential for high growth. Given that these firms were young and had no or little trading record, they were usually not able to meet the listing requirements of the primary markets. The French New Market (Nouveau Marché) was created first and commenced operating on 14 February 1996. At the end of 2000, the total market capitalization of the 158 companies listed on the Nouveau Marché amounted to nearly $€ 14$ billion. The fact that some of its entry requirements were less strict was compensated by other stricter requirements (see Goergen et al., 2003). For example there was no requirement in terms of past profitability, but there was a minimum lock-up period of 6 months (covering $100 \%$ of shares held by the insiders immediately after the IPO) or 1 year (covering $80 \%$ of the insiders' shares) as compared to a 6-month lock-up for all shareholders in the Neuer Markt.

As a consequence of the increasing demand for equity investments in Germany, the Deutsche Börse established the Neuer Markt on 10 March 1997. The number of firms seeking a Neuer Markt listing took off with 11 flotations in 1997 and rose to a spectacular 143 in 2000 . By the end of 2000,325 companies were listed with a market capitalization in excess of $€ 50$ billion.

On 25 March 1997, the Amsterdam Exchanges created a New Market segment: the New Market of the Amsterdam Exchanges (NMAXs). This initiative was soon followed by the Brussels Stock Exchange which created EuroNM Brussels on 11 April 1997. However, in comparison to their French and German counterparts, the EuroNMs of Amsterdam and Brussels have only known a modest success. The total number of IPOs on the Dutch and Belgian markets was 16 and 14, respectively. The youngest EuroNM was the Milanese Nuovo Mercato (later renamed MTAX) which started with the IPO of Opengate SpA, an Italian IT services group on 17 June 1999 and is operated by Borsa Italiana. Whilst today the Nuovo Mercato has only 39 listed companies, it includes Tiscali, one of Europe's largest internet service providers.

Initially, the five EuroNMs experienced a spectacular success with more than 430 companies listed by the end of year 2000 . The total amount of capital raised on the EuroNMs exceeded $€ 23.5$ billion, and the total market capitalization was in excess of $€ 234$ billion (Goergen et al., 2003). The market performance has also been impressive with the official EuroNM All-share Index rising by $561 \%$ between the start of 1998 and March 2000, just prior to the bursting of the 'internet bubble'. However, because of difficulties of harmonizing the different sets of listing rules, the existence of different national regulators and inefficient cross-border trading, the EuroNMs dissolved their partnership in December 2000. Consequently, the five EuroNMs went separate ways: the German Neuer Markt and the Italian Nuovo Mercato went their own ways whereas EuroNext was formed by the merger of the Amsterdam Exchanges (which included the Dutch EuroNM), Brussels Stock Exchange (which included the Belgian EuroNM) and the Paris Bourse (which included the French EuroNM). Since the dissolution of the EuroNMs, the New Markets have suffered particularly badly from the decline in technology stocks with losses on some markets exceeding $80 \%$. Since 2001 , there have been fewer than 20 IPOs on the New Markets down from more than 200 in 2000. After a series of insider trading and price manipulation scandals, Deutsche Börse AG absorbed the Neuer Markt on 5th June 2003. Of all the members of EuroNM network, Neuer Markt was the only exchange that was based on private law. As a result of this it was felt that the regulation was difficult to enforce.

The listing and disclosure requirements on the Neuer Markt and the Nouveau Marché were very similar. For example, for both markets the issuer was required to have at least $€ 1.5 \mathrm{~m}$ of equity capital outstanding. Both markets demanded that the minimum number of shares issued be at least 100,000 and the minimum market capitalization be at least $€ 5 \mathrm{~m}$. Further, for both markets, the issuers were asked to have a minimum free float of $20 \%$ and at least half of the shares offered in the IPO had to be primary shares. Both markets required issuers to adopt the US-GAAP accounting standards and report quarterly accounts. However, in contrast to the Neuer Markt which had a 6-month lock-up period covering all pre-IPO shareholders, ${ }^{3}$ the Nouveau Marché locked up $80 \%$ of the insiders' shares (typically the directors and founders) for a period of 12 months or $100 \%$ of their shares for 6 months.

\section{Literature review}

The second half of the 1990s experienced the busiest IPO market in European history. This was also the period of the birth of the EuroNMs. Goergen et al. (2003) study the underpricing of firms listed on all the EuroNMs. They find that underpricing in the different EuroNM markets was quite high and quite varied. For Germany, average underpricing was around $54 \%$ whereas for France it was around 25\%. The Belgian and Italian IPOs had substantially lower underpricing with 10 and 19\%, respectively. Conversely, IPOs on the

\footnotetext{
${ }^{3}$ For Germany, in addition to the 6-month lock-up, there is a 12-month tax lockup period and a 2-year lock-up period for stock option plans. We are grateful to one of the referees for pointing this out. In what follows, we concentrate on the 6-month lock-up because it is directly comparable to the type of lockups that exist in France.
} 
Dutch EuroNM were on average underpriced by about $86 \%$. The authors argue that the listing rules for the EuroNMs were more lenient than those for the main markets and this led to a more cautious setting of the offer price resulting in higher underpricing. Commenting on the differences in underpricing across the different EuroNM markets, the authors state that the underpricing on the Dutch EuroNM was higher because this market used fixed price offers rather book-built offers as on the other EuroNM markets.

Giudici and Roosenboom (2004) also find that underpricing on the EuroNMs was considerably higher - by about $22 \%$ - than that on the main market segments. They argue that the higher underpricing on the EuroNMs is partially due to reduced incentives to control wealth losses since the insiders sell fewer shares in the IPO. Other factors responsible for the higher underpricing are higher price revisions, the hot issue market and distinct firm characteristics. Arosio, Giudici, and Paleari (2000) focus on the underpricing of internet IPOs on the EuroNMs. They show that underpricing is strongly related to the information gathered during the bookbuilding process. They document that when the final offer price is set at the maximum of the initial price range, the level of underpricing is around $94 \%$ while there is no statistically significant underpricing if the final offer price is set at the minimum of the initial price range. Further, they report that underpricing is higher if the average first-day return of previous IPOs has been higher. However, unlike Giudici and Roosenboom (2004) they do not find a relationship between underpricing and the dilution of insiders' ownership in the IPO.

Franzke (2004) studies the underpricing of German EuroNM IPOs by distinguishing between venture-capital-backed IPOs and those without venture capital. She finds that there is no difference in underpricing between the two types of IPOs. Using the age of the VC as a proxy for its reputation, Franzke reports that the presence of prestigious VCs is associated with higher underpricing. Bessler and Kurth (2007a, 2007b) find that for those IPOs, whose underwriting bank was also providing venture capital to the firm, the level of underpricing is much higher. The authors assert that there are conflicts of interest in the German universal banking system which become evident when studying IPOs on the Neuer Markt. Tykvová and Walz (2007) study the same issue but partition the German VCs into more detailed categories such as state owned, bank affiliated, corporate and independent VCs. They also examine their relation to underpricing and post-issue performance. Though they do not find any statistically significant differences in underpricing between IPOs backed by the different types of VCs, they do find that firms backed by independent, international and reputable VCs outperform other IPOs over the long run.

Several other IPO characteristics have been examined for the firms listed on the Neuer Markt. For example, Franzke and Schlag (2002) focus on over-allotment options (Greenshoe options). They hypothesize that firms with an over-allotment option have lower underpricing, but do not find supporting evidence of this. Bessler and Stanzel (2007) investigate the independence of analysts who make earnings forecasts for German IPOs. Their results show that major conflicts of interest emerge when the analyst works for the underwriter of the issue. Rocholl (2007) studies the relationship between executive stock option plans and underpricing. He finds that for those companies where the strike price of the stock option is equal to the offer price at the time of the IPO, the level of underpricing is higher as compared to the underpricing of companies that choose a strike price equal to the stock price on the first day of trading. He also reports that the level of underpricing is positively influenced by the extent of allocations via family and friends programmes.

For France, there also exist several studies on the relationship between IPO underpricing and the venture-capital industry.
Chahine, Filatotchev, and Wright (2007) find that French VC-backed IPOs show higher underpricing than IPOs without VC backing. Chahine and Filatotchev (2008) find that when VCs are affiliated to the lead underwriters, the level of underpricing was lower than that for IPOs backed by non-affiliated VCs. This result stands in marked contrast with the one found by Bessler and Kurth (2007a, 2007b) for German IPOs.

In this paper, we investigate the likely causes for the high underpricing and the reasons for the large difference in underpricing between the different EuroNM markets. Specifically, we focus on ownership dilution at the time of the IPO, investor demand, lock-up periods for the VCs and the other shareholders, and the presence of the underwriting bank as a shareholder in the IPO firm. These characteristics are largely unique to the EuroNM markets and have not been sufficiently investigated in the abovementioned papers.

Nevertheless, recent studies of underpricing in the US markets during the dot com bubble provide some reasons why underpricing was so severe during this bubble. For instance, Ljungqvist and Wilhelm (2003) document that, for a sample of internet IPOs during 1999-2000, the level of underpricing was $89 \%$, about five times the level in the mid-1990s. They find that the high underpricing is partially due to marked changes in the pre-IPO ownership structure and the insider selling behaviour in the IPO. During the bubble, preIPO ownership was fragmented, the pre-IPO stakes of CEOs were half the pre-bubble level, and the frequency and magnitude of secondary sales by all insiders was smaller. There were also larger price revisions.

In addition, Loughran and Ritter (2004) argue that part of the increase in IPO underpricing during the dot com bubble can be attributed to the higher risk of these firms, which gives support to the changing risk composition hypothesis. Unlike Ljungqvist and Wilhelm (2003), Loughran and Ritter do not find a relation between the sale of secondary shares and underpricing. In fact, they find that CEO ownership, as measured by the dollar value of holdings at the offer price, was twice as high during the dot com bubble period as compared to earlier periods. They argue that this should have led to decreased underpricing during the bubble period. They attribute much of the higher underpricing during the bubble period to a changing issuer objective function and argue that during this period there was less focus on maximising IPO proceeds due to an increased emphasis on analyst coverage. Issuing firms were seeking to hire highly reputable underwriters with highly ranked analysts even if they came at the cost of higher underpricing (the analyst lust hypothesis). In addition, beginning in the 1990s, the underwriters were making side payments to the executives of the issuing firms in the form of share allocations in hot IPOs. This practice created an incentive for the issuing firm's management to seek rather than to avoid underwriters with a reputation of severe underpricing (the spinning hypothesis).

There are alternative explanations for the severe underpricing of US IPOs during the bubble period. For example, Aggarwal, Krigman, and Womack (2002) argue that issuers at the time of the bubble were willing to underprice more in order to generate an information momentum (by attracting attention to the stock) resulting in higher market prices at the end of the lock-up period when insiders typically sell some of their shares. Finally, DuCharme, Rajgopal, and Sefcik (2002) state that the high underpricing of internet IPOs was partly because of the media hype prior to the going public.

\section{The determinants of underpricing}

The theoretical literature on IPOs suggests a number of reasons for underpricing. For example, IPOs are underpriced because of underwriters' risk aversion, information asymmetry and the winner's curse, insurance against litigation, and compensation to 
(institutional) investors for revealing truthful information about the demand for shares. ${ }^{4}$ Below, we focus on the likely determinants of underpricing in the context of the dot com bubble.

\subsection{Ownership dilution}

Habib and Ljungqvist (2001) develop a model which relates underpricing to the insiders' participation in the offering and the magnitude of the dilution they suffer on the shares they retain. They argue that if the insiders sell a large number of their shares in the IPO, then they should be more concerned about the level of underpricing. Habib and Ljungqvist show that the larger the sale of secondary shares by the insiders, the lower is the underpricing. Similarly, the greater the dilution factor or the increase in the shares outstanding (as a result of the issuance of primary shares), the smaller is the level of underpricing. Therefore we hypothesize:

Hypothesis 1. Larger insider participation in the offering and larger ownership dilution lead to lower underpricing.

Similar to Habib and Ljungqvist, we measure the level of insider selling by the issue participation ratio which is defined as the number of secondary shares sold in the IPO divided by the total number of shares outstanding in the pre-IPO period. The dilution factor is defined as the number of primary shares issued in the IPO divided by the total number of shares outstanding before the IPO.

\subsection{Venture capital}

Venture capitalists are important providers of finance to firms with a high growth potential. They not only provide the necessary capital but their presence also signals the firm's quality as they usually monitor the firm's management and are also otherwise involved in the decision-making process (e.g. Barry, 1994; Jain \& Kini, 2000). Barry, Muscarella, Peavy, and Vetsuypens (1990) report that, in a sample of VC-backed US companies, VCs hold substantial stakes and provide intensive monitoring. They also report that, contrary to conventional wisdom, VCs frequently keep their shareholdings a long time after the IPO. Hence, VCs may mitigate agency problems as well as more general problems arising from asymmetric information. Hence, we expect that underpricing of VC-backed firms is less severe:

Hypothesis 2. Firms that are backed by VCs have less underpricing than firms without VC financing.

\subsection{Price revisions}

Once the underwriter discloses the indicative price range (the book-building range) for the issue, information on the potential demand of the issue is collected from investors (for example through road shows). Benveniste and Spindt (1989) argue that potential investors need compensation for revealing truthful information about the demand for the issue. The underwriter will revise the price upwards if it receives favourable information from the investors. However, it will increase the issue price to a level below the 'fair price' suggested by the newly revealed information (the partial adjustment phenomenon). This causes underpricing which compensates the investors who have revealed truthful information. In order to guarantee the disclosure of favourable information, the price adjustment that follows the disclosure of bad news will be less

\footnotetext{
${ }^{4}$ For a discussion of these and other reasons for underpricing, see Jenkinson and Ljungqvist (2001).
}

substantial, resulting in less underpricing, than that following good news. Ljungqvist and Wilhelm (2003) formulate similar arguments.

Hypothesis 3. A higher positive price revision leads to higher underpricing.

The price revision is measured as the percentage difference between the final offer price of the shares and the mid-point of the book-building range. ${ }^{5}$

\subsection{Lock-up periods vs. underpricing}

Espenlaub, Goergen, and Khurshed (2001) and Brau, Lambson, and McQueen (2004) argue that issuers with more substantial information asymmetries should have longer lock-up periods. The literature also predicts that firms with high ex ante uncertainty have higher underpricing. Further, the lock-up length and the underpricing may act as complementary devices. In contrast, Goergen, Renneboog, and Khurshed (2006) argue that underpricing is a substitute to the lock-up length and, therefore, firms that use higher underpricing should have shorter lock-up lengths. They find support for their assertion for a sample of French IPOs that show a negative relationship between underpricing and lock-up length. This discussion leads us to the following two competing hypotheses:

Hypothesis 4a. Underpricing is a complement to the lock-up length.

Hypothesis 4b. Alternatively, underpricing is a substitute to the lock-up length. A longer lock-up length is accompanied by less underpricing.

For every shareholder of every firm in our sample, we do not only measure the length of the lock-up period but also the percentage of his/her shares locked up. We classify shareholders as insiders (executives and founder-owners), VCs, and outsiders (all other types of shareholders). A major difference between German and French minimum lock-ups is that the former apply to all the pre-IPO shareholders who still hold shares immediately after the IPO whereas the latter only apply to the insiders (executives and founder-owners). As mentioned above, the German EuroNM IPOs, the minimum lock-up period is 6 months after the IPO. For all the afore-mentioned categories of shareholders, we calculate the percentage of post-IPO shares locked up at the minimum requirement as well as that locked up beyond the minimum requirement. IPOs on the Nouveau Marché can choose between two alternative minimum lock-up contracts: a lock-up covering 100\% of the shares for 6 months or one covering $80 \%$ of the shares for 12 months. Goergen et al. (2006) show that, for France, these two minimum requirements are not equivalent and that the longer contract - despite covering only $80 \%$ of the shares - is perceived as more stringent. Therefore, we calculate the percentage of post-IPO shares locked up at the first minimum requirement (6 months with 100\%), locked up at the second minimum requirement ( 1 year with $80 \%$ ), and locked up beyond the two minimum requirements. In addition, for France, we also calculate the percentage of VC shares not locked up.

\subsection{Underwriter's stake vs. underpricing}

An interesting feature of the German and French EuroNM markets is that, in about $15 \%$ of the German IPOs and $10 \%$ of the French ones, the underwriter hired by the issuer is also a preIPO shareholder. This creates a dilemma for the underwriter. If the

\footnotetext{
5 As a robustness check we also use the oversubscription levels as a proxy for investor demand. We are only able to do this for the French market as the equivalent
} data for the German market are not available. 
Table 1

Variables used and hypotheses tested.

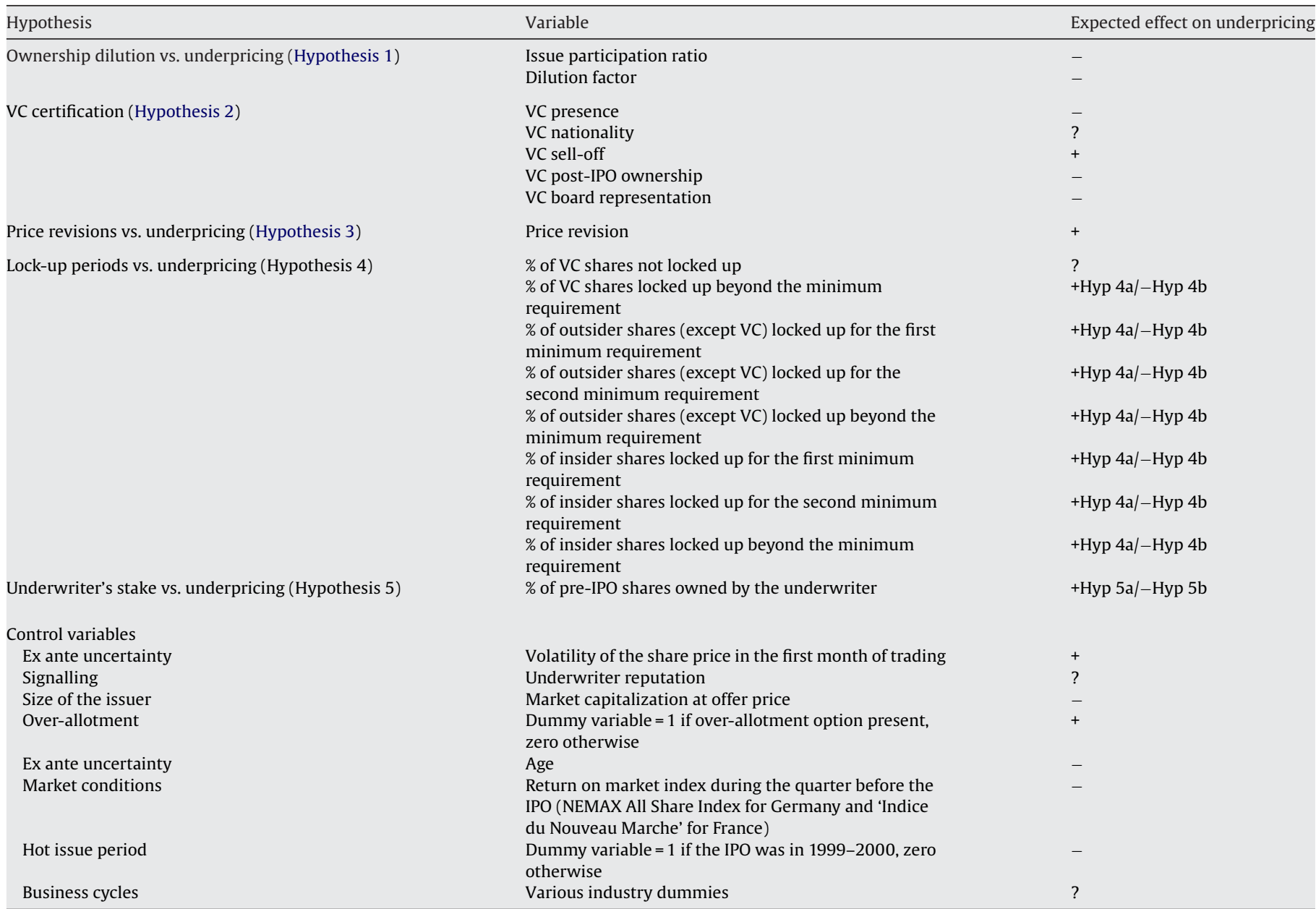

underwriter underprices the issue heavily, it will incur a personal wealth loss on the share stake it is selling in the IPO, but the underpricing may also generate repeat business from clients who have been allocated some of the underpriced shares. In contrast, if the underwriter's setting of the price creates only modest underpricing, its personal wealth loss will be relatively small and so will be the chances of repeat business. We arrive at the following two competing hypotheses:

Hypothesis 5a. IPOs, whose underwriter is also a pre-IPO shareholder, show higher underpricing.

Hypothesis 5b. IPOs, whose underwriter is also a pre-IPO shareholder, show smaller underpricing.

We measure the underwriter's ownership by the shareholding of the underwriter expressed as a percentage of the shares outstanding before the IPO.

In addition to the variables described above, we also use a number of control variables such as the volatility of the share price in the first month of trading (to capture the ex ante uncertainty of the firm), ${ }^{6}$ firm age, a dummy variable capturing whether there

6 We follow Ritter (1987) in measuring the ex ante riskiness of an IPO firm. Ritter (1987) asserts that an observable variable that is related to ex ante uncertainty of an IPO firm is the daily standard deviation of returns in the aftermarket. He argues that it is highly likely that firms with highly volatile share prices are the ones that had a highly uncertain market value in the pre-IPO period. Ritter uses the standard deviation of returns for the first month of trading. was an over-allotment option, and industry and time dummies. We also include lagged market returns (based on the NEMAX All Share Index for Germany and 'Indice du Nouveau Marché' for France) measured over the quarter preceding the IPO in order to examine whether the degree of underpricing is correlated to past stock market movements (as do Loughran \& Ritter, 2002). Table 1 summarises the hypotheses, the variables used and the predicted signs of their coefficients.

\section{Data sources and sample description}

Over the period of 1996/1997-2000, there were 325 IPOs on the German market and 158 IPOs on the French market. ${ }^{7}$ We only consider IPOs by domestic firms and exclude all IPOs by foreign firms as well as transfers from other markets. IPOs by banks and insurance firms are also excluded. As there are a few firms with missing prospectuses and first-day trading prices, our final sample consists of 265 flotations on the German market and 136 on the French market.

\footnotetext{
7 The German market started operating in 1997. Our sample period ends in 2000 due to the collapse of the IPO market subsequent to the equity market crash in March 2001. There were 11 IPOs in Germany during the year 2001 which we did not consider in the study. Most of these were 'cold' IPOs. We acknowledge the possibility of a small bias in our results because of this exclusion.
} 
Table 2

Descriptive statistics of German and French firms floated on the European New Markets. Age is calculated as the number of full years between the year of foundation and the year of the flotation. Market capitalization is measured at the end of the first day of trading. Price revision is the ratio of the difference between the offer price and the mid-point of the book-building range divided by the mid-point of the book-building range. Over-allotment options allow underwriters to underwrite up to an additional $15 \%$ of shares in an IPO. The issue participation ratio is the number of secondary shares sold at the time of the IPO divided by the number of pre-IPO shares outstanding. The dilution factor is the number of primary shares issued divided by the number of pre-IPO shares outstanding. . Under the null hypothesis that the two proportions are identical, $Z$ is approximately distributed as a standard normal deviate (Kanji, 1995).

\begin{tabular}{lcc}
\hline & Germany & France \\
\hline Age (in years) & 13.05 & $11.17^{* *}$ \\
$\begin{array}{l}\text { Average market capitalization on first } \\
\quad \text { trading day (€ million) }\end{array}$ & 314.35 & $75.94^{* * *}$ \\
\% of IPOs which are VC-backed & 46.8 & \\
Average lock-up length (months) & 9.5 & $56.8^{++}$ \\
\% of IPOs that used book-building & 99.3 & 10.4 \\
\% of IPOs priced at the upper bound of & 75.4 & 100 \\
$\quad$ the book-building range & & $51.6^{+++}$ \\
Average price revision (\%) & 4.23 & \\
\% of IPOs with over-allotment options & 89.18 & $2.70^{*}$ \\
\% of IPOs during the dot com bubble & 82.84 & $45.65^{+++}$ \\
$\quad$ period (1999-2000) & & $52.17^{+++}$ \\
Issue participation ratio (\%) & 9.26 & $6.54^{* * *}$ \\
Dilution factor (\%) & 34.37 & $32.14^{*}$ \\
\hline
\end{tabular}

Statistical significance for the two-tailed $t$-test on the difference in means between Germany and France at the $10 \%$ level.

** Statistical significance for the two-tailed $t$-test on the difference in means between Germany and France at the $5 \%$ level.

*** Statistical significance for the two-tailed $t$-test on the difference in means between Germany and France at the $1 \%$ level.

${ }^{++}$Statistical significance at the $5 \%$ level for the two-tailed Z-test for the equality between two proportions in two samples, assuming a binomial distribution.

${ }^{+++}$Statistical significance at the $1 \%$ level for the two-tailed $Z$-test for the equality between two proportions in two samples, assuming a binomial distribution.

Information on IPOs such as the date of the IPO, the offer price and other listing particulars were obtained directly from the exchanges. Firm specific information such as firm age, underwriters of the issue, shares sold in the IPO, lock-up agreements and the presence of VCs were hand-collected from the listing prospectuses. For the German market we completed the data using the annual volumes of the Hoppenstedt Aktienführer and data from Deutsche Bank $A G$. The first-day share prices as well as information on industrial sectors were obtained from Datastream.

Table 2 shows the characteristics of the IPOs on the German and French EuroNMs. The firms are significantly younger than IPOs on the first and second-tier exchanges. For example, the average age of an IPO firm on the Neuer Markt is about 13 years whereas the average age of German IPOs on the Official and Regulated Markets is more than 49 years (Goergen \& Renneboog, 2003). For the Nouveau Marché, the average age of IPOs is about 11 years compared to 30 years for IPOs on the other French markets (Chahine, 2008). The market capitalization of the average French IPO is about four times smaller than that of the average German IPO (the difference is significant at the $5 \%$ level). In both markets, venture capitalists have a strong presence with nearly $47 \%$ of the German firms and $57 \%$ of the French firms having at least one VC among their shareholders (the difference is significant at the $5 \%$ level). Interestingly, the average length of lock-up agreements for both the markets is similar (around 10 months) despite the different rules on the minimum lock-up length.

Book-building is the pricing method used for all the IPOs in both markets. ${ }^{8}$ We find that, for the majority of the German IPOs (about

\footnotetext{
8 Only one firm in Germany did not use a book-building procedure.
}

$75 \%$ ), the final offer price is the same as the upper bound of the bookbuilding range. For only about $8 \%$ of the IPOs, the final offer price is set at the lower bound. Few IPOs (only about 3\%) are priced below the book-building range. The majority of the IPOs whose final offer price is set at or below the lower bound came to the market in late 1999-2000, which was the period when the internet bubble was about to burst. In contrast, only about half of the French IPOs (about $51 \%$ ) are priced at the upper bound of their book-building range and for nearly $15 \%$ the offer price is set at the lower bound. Similar to the German IPOs, few French IPOs (about 4\%) are priced below the book-building range. However, in contrast to Germany, there are a few French IPOs which are priced above the book-building range (only about 2\%). The fact that for most of the German EuroNM IPOs the offer price was set at the top end of the book-building range indicates the high demand for the German new economy IPOs at that time. The demand for French IPOs seems to have been lower.

One new and interesting feature of the German and French EuroNM IPOs is the provision of over-allotments (Greenshoe) options which provide underwriters with the option to sell additional shares (usually about $15 \%$ of the shares being sold in the IPO) in the market if demand is high. Over-allotment options are much more prevalent in Germany where about $90 \%$ of IPOs have them as compared to less than half in France (the difference is significant at the $5 \%$ level for the $Z$-test on the difference between two proportions assuming a binomial distribution).

The German and French EuroNM IPOs also differ in terms of their timing. The majority of IPOs in the German EuroNM went public at the height of the dot com bubble years (1999 and 2000) whereas only about half of the French IPOs were floated in those years (the difference is significant at the $5 \%$ level). Finally, the owners of the German IPOs sell a higher fraction of their holdings with an average issue participation ratio of $9.26 \%$ in comparison to their French counterparts which have an average issue participation ratio of $6.54 \%$ (the difference is significant at the $5 \%$ level). In addition, the dilution factor in Germany (34\%) is also higher than that in France (32\%), the difference being significant at the 5\% level. Hence, for both markets the existing owners saw on average one-third of their ownership being diluted as a result of primary shares sold in the IPO.

\section{Underpricing in the Neuer Markt and the Nouveau Marché}

Table 3 shows the level of underpricing for the German and French EuroNMs during the period of 1996-2000. The average underpricing for the German EuroNM is around 53\% while that for the French EuroNM IPOs is substantially lower at $21 \%$. This level of underpricing is unprecedented for both markets as the historical level of underpricing of IPOs in Germany and France has been around 10\% (see Ljungqvist, 1997 for Germany and Derrien \& Womack, 2003 for France). However, it is still substantially lower than the underpricing of $89 \%$ in the US market during the same period (see Ljungqvist \& Wilhelm, 2003). For Germany, the level of underpricing surges abruptly from about 34\% in 1997 to about $74 \%$ in 1998 and averages $51 \%$ in subsequent years. Overall, the yearly (average and median) underpricing for Germany is always significantly higher than that for France.

\subsection{Underpricing by industry}

Panel A of Table 4 shows a cross-sectional analysis of IPO underpricing by industry. The majority of IPOs ( $64.9 \%$ in Germany and $59.3 \%$ in France) are in the Business Services industry (SIC 7089) which has the highest underpricing amongst all industries in Germany. For France, the largest underpricing occurs in the Trans- 
Table 3

Yearly underpricing on the Neuer Markt and the Nouveau Marché.

\begin{tabular}{|c|c|c|c|c|c|c|}
\hline \multirow[t]{2}{*}{ Year } & \multicolumn{2}{|c|}{ No. of IPOs } & \multicolumn{2}{|c|}{ Average first-day returns (\%) } & \multicolumn{2}{|c|}{ Median first-day returns (\%) } \\
\hline & Germany & France & Germany & France & Germany & France \\
\hline 1996 & - & 12 & - & 5.95 & - & 6.71 \\
\hline 1997 & 9 & 16 & 33.95 & 15.64 & 24 & $0.01^{+}$ \\
\hline 1998 & 36 & 36 & 73.65 & $20.65^{* * *}$ & 61.65 & $2.18^{+++}$ \\
\hline 1999 & 106 & 28 & 51.04 & $22.46^{* * *}$ & 24.5 & $8.85^{++}$ \\
\hline 2000 & 114 & 44 & 49.54 & $26.25^{* *}$ & 20.26 & $2.28^{+++}$ \\
\hline 1996/1997-2000 & 265 & 136 & 52.89 & $21.06^{* * *}$ & 28.67 & $3.28^{+++}$ \\
\hline
\end{tabular}

${ }^{* *}$ Statistical significance of the two-tailed $t$-test on difference in means between Germany and France at the $5 \%$ level.

${ }^{* * *}$ Statistical significance of the two-tailed $t$-test on difference in means between Germany and France at the $1 \%$ level.

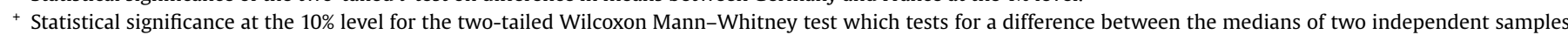
with similarly shaped distributions.

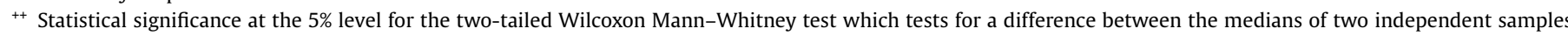
with similarly shaped distributions.

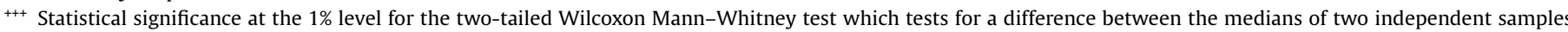
with similarly shaped distributions.

port and Public Utilities industry (SIC 40-49), although it should be noted that the number of IPOs in this industry is small (6 firms). For both markets, the second most important industry in terms of the number of IPOs is Manufacturing (SIC 20-39). Underpricing in this industry is high both for Germany (46.52\%) and France $(26.07 \%)$. When we delve into the various sectors forming the Business Services industry, we find that the majority of the IPOs from this industry occur in computer-related services such as computer programming, pre-packaged software, integrated systems design and computer-related services. In contrast, Cockburn and Wagner (2007) find that the majority of US computer industry IPOs (1998-2001) came from internet services and software sectors. Panel B of Table 4 shows the level of underpricing in these sectors. The underpricing is larger in virtually all sectors of the Business Services industry in Germany. This is in line with the findings of Guo, Lev, and Chi (2006) who show that IPOs of technology firms (with high R\&D) are more underpriced than other firms (with little investment in R\&D).

\subsection{Ownership dilution vs. underpricing}

Panel A of Table 5 shows the importance of the different types of pre-IPO shareholders in Germany and France. In both the markets, the majority of the IPO firms (70.85\% in Germany and $79.66 \%$ in France) have a family or an individual (such as the founder) as their shareholder. Ownership by this type of shareholder is significantly higher at the $10 \%$ level in France than in Germany. About $12 \%$ of the German and $11 \%$ of the French firms have VCs as among their pre-IPO owners. Other companies such as banks and financial institutions are present as one of the owners in 16.19\% of the German and $9.32 \%$ of the French firms (the difference is significant at the $10 \%$ level).

Habib and Ljungqvist (2001) argue that insiders are more tolerant of underpricing if they sell fewer shares in the IPO. Their data corroborates their hypothesis for the case of US IPOs in 1999-2000. We verify whether this is also the case for the IPOs on the EuroNMs. Panel B of Table 5 shows the underpricing for firms with below and above-median participation and dilution ratios. Whereas underpricing differs significantly between firms with above-median and below-median issue participation/dilution ratios and also across the two countries, we do not find a relationship between underpricing on one side and the level of insider participation and the dilution of their ownership at the flotation on the other side.

\subsection{VCs and underpricing}

Table 6 reports the presence of VCs in the German and French EuroNM markets before the IPO as well as the degree of their exit at the time of the IPO. Panel A of Table 6 shows that about $47 \%$ of the

Table 4

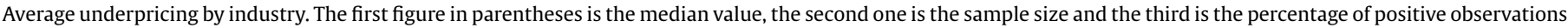
Panel A: Average underpricing by industry

\begin{tabular}{|c|c|c|}
\hline Industry & Germany & France \\
\hline SIC 20-39, Manufacturing & $46.52 \%(29.17 \%, 51,86.27 \%)$ & $26.07 \%^{* *}(10.25 \%, 33,78.13 \%)$ \\
\hline SIC 40-49, Transport and Public Utilities & $23.5 \%(15.00 \%, 18,58.82 \%)$ & $67.41 \%(2.14 \%, 6,80 \%)$ \\
\hline SIC 50-51, Wholesale Trade & $54.95 \%(27.81 \%, 13,100 \%)$ & $5.58 \%(0.1 \%, 10,60 \%)$ \\
\hline SIC 52-59, Retail Trade & $42.65 \%(0.00 \%, 5,40 \%)$ & $-0.35 \%(0.04 \%, 6,60 \%)$ \\
\hline SIC 60-67, Finance, Insurance, Real Estate & $35.53 \%(17.92 \%, 7,83.33 \%)$ & - \\
\hline SIC 70-89, Business Services & $60.68 \%(30.37 \%, 174,82.66 \%)$ & $19.92 \%{ }^{* * *}(4.4 \%, 80,62.50 \%)$ \\
\hline
\end{tabular}

Panel B: Average underpricing within different sectors of Business Services industry (SIC 73)

\begin{tabular}{|c|c|c|}
\hline SIC 73, Business Services (computer) & Germany & France \\
\hline SIC 7371, custom computer prog. services & $63.78 \%(33.33 \%, 42,92.68 \%)$ & $13.5 \%(14.29 \%, 9,66.67 \%)$ \\
\hline SIC 7372, pre-packaged software & $67.2 \%(50.48,21,85.71 \%)$ & $14.41 \%(4.38 \%, 18,72.22 \%)$ \\
\hline SIC 7373, comp.-integrated systems design & $44.47 \%(30.00 \%, 23,78.26 \%)$ & $114.64 \%(130.79 \%, 4,100 \%)$ \\
\hline SIC 7379 , computer-related services & $35.4 \%(35.40 \%, 21,79.17 \%)$ & $11.76 \%(0.00 \%, 8,42.86 \%)$ \\
\hline For all IPOs in SIC 73 & $56.13 \%(30.40 \%, 107,83.33 \%)$ & $25.39 \%^{* * *}(4.4 \%, 39,59.26 \%)$ \\
\hline
\end{tabular}

${ }^{* *}$ Statistical significance of the two-tailed $t$-test on the difference in means between Germany and France at the $5 \%$ level.
Statistical significance of the two-tailed $t$-test on the difference in means between Germany and France at the $1 \%$ level. 
Table 5

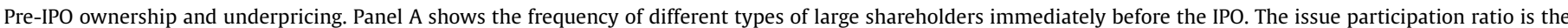

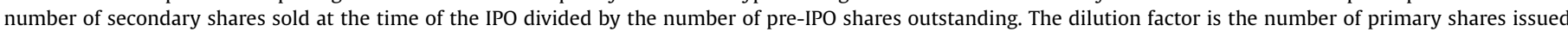

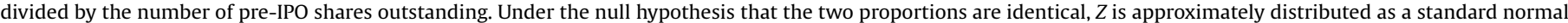
deviate (Kanji, 1995).

\begin{tabular}{|c|c|c|c|}
\hline & Germany (\% of firms) & France $(\%$ & \\
\hline \multicolumn{4}{|l|}{ Pre-IPO ownership by } \\
\hline Family or individual & 70.85 & $79.66^{+}$ & \\
\hline Venture capitalist & 12.15 & 11.02 & \\
\hline Other companies & 16.19 & $9.32^{+}$ & \\
\hline Own shares & 0.40 & 0.00 & \\
\hline Holding company/trust & 0.40 & 0.00 & \\
\hline \multicolumn{4}{|c|}{ Panel B: Underpricing and the extent of insider participation at the IPO } \\
\hline & Germany (underpricing) & France (underpricing) & $t$-Test: difference in means \\
\hline \multicolumn{4}{|l|}{ Issue participation ratio } \\
\hline Below median & $50.91 \%$ & $24.85 \%$ & $3.13^{* * *}$ \\
\hline Above median & $54.70 \%$ & $13.88 \%$ & $5.70^{* * *}$ \\
\hline$t$-Test: difference in means & -0.44 & 1.59 & \\
\hline \multicolumn{4}{|l|}{ Dilution factor } \\
\hline Below median & $54.95 \%$ & $20.67 \%$ & $4.21^{* * *}$ \\
\hline Above median & $50.48 \%$ & $18.16 \%$ & $4.07^{* * *}$ \\
\hline$t$-Test: difference in means & 0.50 & 0.36 & \\
\hline
\end{tabular}

+ Statistical significance at the $10 \%$ for the two-tailed $Z$-test for the equality between two proportions from two samples, assuming a binomial distribution.

*** Statistical significance of the two-tailed $t$-test on the difference in means between Germany and France at the $1 \%$ level.

German and 57\% of the French IPOs are backed by VCs. Out of the 99 different VCs operating in the German IPO market, 25 are domestic (i.e. they are members of the German VC association), while the remaining 74 are members of one or more foreign VC associations. Nine VCs are members of more than four international VC associations and invest in more than a third of all German firms with VC backing. Out of the 69 VCs on the French IPO market, 44 are domestic while the remaining 25 are members of one or more foreign VC associations. Three VCs (ABN AMRO, 3i and Apax Part-

\section{Table 6}

Characteristics of German and French VCs and their exit behaviour at the IPO. Domestic VCs are those that are members of the domestic VC association only. International VCs are those that are members of at least one VC association from outside their country of domicile. They may or may not be a member of their domestic VC association. Under the null hypothesis that the two proportions are identical, $Z$ is approximately distributed as a standard normal deviate (Kanji, 1995).

\begin{tabular}{|c|c|c|}
\hline & Germany & France \\
\hline \multicolumn{3}{|l|}{ Panel A: VC backing before the IPO } \\
\hline$\%$ of IPOs with VC backing & $46.8 \%$ & $56.8 \%^{++}$ \\
\hline Total number of different VCs & 99 & 69 \\
\hline \multicolumn{3}{|l|}{ present } \\
\hline \multicolumn{3}{|l|}{ Of these } \\
\hline Domestic & $25.25 \%$ & $63.8 \%^{+++}$ \\
\hline International & $74.75 \%$ & $36.2 \%^{+++}$ \\
\hline$\%$ of VC-backed firms with more & $41.1 \%$ & $69.6 \%^{+++}$ \\
\hline \multicolumn{3}{|l|}{ than $1 \mathrm{VC}$ as a backer } \\
\hline Average number of VCs per firm & 2 & 2.5 \\
\hline \multicolumn{3}{|c|}{ Panel B: Exit behaviour of VCs in the IPO } \\
\hline $\begin{array}{l}\% \text { of firms with VCs retaining all } \\
\text { shares }\end{array}$ & $27.2 \%$ & $41.8 \%^{++}$ \\
\hline$\%$ of firms with VCs selling up & $31.2 \%$ & $37.3 \%$ \\
\hline \multicolumn{3}{|l|}{ to $25 \%$ of their shareholdings } \\
\hline$\%$ of firms with VCs selling & $25.6 \%$ & $14.9 \%^{+}$ \\
\hline \multicolumn{3}{|l|}{ between 25 and $50 \%$} \\
\hline $\begin{array}{l}\% \text { of firms with VCs selling more } \\
\text { than } 50 \%\end{array}$ & $16.0 \%$ & $6.0 \%^{++}$ \\
\hline
\end{tabular}

${ }^{+}$Statistical significance at the $10 \%$ level for the two-tailed $Z$-test for the equality between two proportions from two samples, assuming a binomial distribution.

${ }^{++}$Statistical significance at the $5 \%$ level for the two-tailed $Z$-test for the equality between two proportions from two samples, assuming a binomial distribution.

${ }^{+++}$Statistical significance at the $1 \%$ level for the two-tailed $Z$-test for the equality between two proportions from two samples, assuming a binomial distribution. ners) account for more than a quarter of all the VC-backing in the French IPOs. About $41 \%$ of the German firms are backed by more than one VC. For example, there is a consortium of 12 different VCs in GPC Biotech AG. However, the average number of VCs per firm is only 2 with a median value of 1 . In comparison, almost $70 \%$ of the French VC-backed IPOs have more than one VC as an investor. For example, ESI Group SA has 13 VCs, while the average number of VCs per French firm is 2.5 with a median of 2 . We also find that there are only eight venture capitalists that operate in both the German and French EuroNMs. Out of these, 3i backs 21 German IPOs and 6 French IPOs, and ABN AMRO backs 8 French firms and one German IPO.

Panel B of Table 6 gives information on the exit behaviour of VCs in the IPO. In about $27 \%$ of the VC-backed German firms, VCs hold onto all of their shares in the IPO. In about $31 \%$, VCs sell up to $25 \%$ of their pre-IPO holdings, and in a quarter of German firms, VCs sell between 25 and 50\%. In only four firms, VCs liquidate all of their shareholdings. In one exceptional case, a VC bought shares in a firm at the time of flotation. In comparison, in about $42 \%$ of French VC-backed firms, the VCs retain all their shares at the IPO. In about $37 \%$ of the firms, the VCs sell up to $25 \%$ of their pre-IPO shares and in 15\% of the IPOs they sell between 25 and $50 \%$. In only $6 \%$ of the IPOs, the VCs liquidate more than $50 \%$ of their holdings, but none liquidates more than $70 \%$ of its shareholdings. This shows that, apart from a few exceptions, in both German and French IPOs, VCs retain most of their shares after the IPO. To summarise Table 6, we find that the VCs of Germany and France are quite different in terms of their presence, number and consortium size at the time of the IPO. Later in our analysis, we will test if the differences in VC lock-ups in Germany and France explain the large difference in underpricing in the two markets.

For the German EuroNM IPOs, we extend the studies of Franzke (2004) and Bessler and Kurth (2007a, 2007b) by using other measures of VC reputation such as the domestic or international character of the VC, and whether the VC is UK/US-based or not. We also look at various other characteristics of VCs such as their sales in the IPO, the level of their post-IPO ownership and whether the $\mathrm{VC}$ is on the supervisory board of the issuing firm. Table 7 shows the level of underpricing in relation to the different VC characteristics. 
Table 7

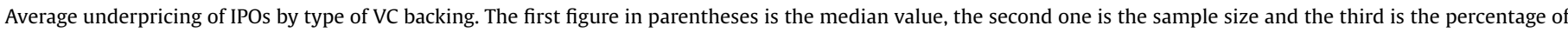

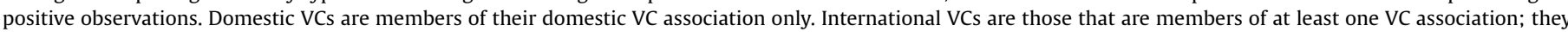
may or may not be a member of their domestic VC association.

\begin{tabular}{|c|c|c|c|}
\hline & Germany (underpricing) & France (underpricing) & $t$-Test for difference in means \\
\hline VC present at IPO & $50.77 \%(28.76 \%, 124,81.45 \%)$ & $21.00 \%(2.56 \%, 71,57.74 \%)$ & $3.77^{* * *}$ \\
\hline No VC present at IPO & $54.75 \%(28.57 \%, 141,81.56 \%)$ & $19.10 \%(0.01 \%, 57,52.63 \%)$ & $4.31^{* * *}$ \\
\hline$t$-Test for difference in means & 0.48 & -0.24 & \\
\hline$P$-value for difference in medians & 0.89 & 0.60 & \\
\hline Domestic VC & $54.48 \%(28.67 \%, 43,79.07 \%)$ & $16.01 \%(3.28 \%, 36,61.11 \%)$ & $-3.19^{* * *}$ \\
\hline International VC & $53.55 \%(29.61 \%, 82,82.93 \%)$ & $19.99 \%(7.20 \%, 32,56.25 \%)$ & $-3.26^{* * *}$ \\
\hline$t$-Test for difference in means & 0.07 & -0.44 & \\
\hline$P$-value for difference in medians & 0.98 & 0.94 & \\
\hline UK/US based VC & $59.50 \%(36.94 \%, 44,86.36 \%)$ & $24.84 \%(5.28 \%, 17,52.94 \%)$ & $-2.13^{* * *}$ \\
\hline Non-UK/US based VC & $50.82 \%(20.52 \%, 81,79.01 \%)$ & $15.32 \%(3.40 \%, 51,62.50 \%)$ & $-4.06^{* * *}$ \\
\hline$t$-Test for difference in means & -0.69 & -0.70 & \\
\hline$P$-value for difference in medians & 0.27 & 0.83 & \\
\hline Below-median sell-off by the VCs & $52.32 \%(28.28 \%, 62,83.87 \%)$ & $15.33 \%(5.28 \%, 33,60.61 \%)$ & $-3.53^{* * *}$ \\
\hline Above-median sell-off by the VCs & $56.30 \%(30.52 \%, 62,80.65 \%)$ & $17.41 \%(3.05 \%, 32,59.38 \%)$ & $-3.62^{* * *}$ \\
\hline$t$-Test for difference in means & -0.32 & -0.24 & \\
\hline$P$-value for difference in medians & 0.83 & 0.98 & \\
\hline Below-median post-IPO ownership of VCs & $53.52 \%(26.83 \%, 62,77.42 \%)$ & $13.07 \%(4.43 \%, 34,55.88 \%)$ & $-3.95^{* * *}$ \\
\hline Above-median post-IPO ownership of VCs & $54.85 \%(30.13 \%, 62,85.48 \%)$ & $22.28 \%(3.53 \%, 34,58.82 \%)$ & $-2.90^{* * *}$ \\
\hline$t$-Test for difference in means & -0.11 & -1.03 & \\
\hline$P$-value for difference in medians & 0.51 & 0.96 & \\
\hline $\mathrm{VC}$ is a member of the supervisory board & $67.35 \%(31.10 \%, 30,90 \%)$ & $20.00 \%(9.60 \%, 34,58.82 \%)$ & $2.80^{* * *}$ \\
\hline VC is not a member of the supervisory board & $49.62 \%(28.67 \%, 95,78.95 \%)$ & $15.39 \%(2.14 \%, 35,60.61 \%)$ & $3.97^{* * *}$ \\
\hline$t$-Test for difference in means & 1.06 & 0.52 & \\
\hline$P$-value for difference in medians & 0.40 & 0.63 & \\
\hline
\end{tabular}

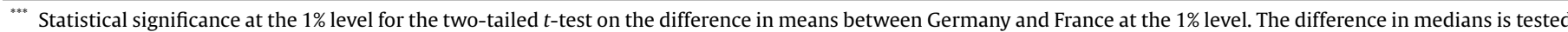
by the two-tailed Wilcoxon Mann-Whitney test which tests for a difference between the medians of two independent samples with similarly shaped distributions.

For Germany, the average level of underpricing for VC-backed firms is $50.77 \%$ compared to $54.75 \%$ for firms without a VC. For France, VC-backed IPOs experience an average underpricing of $21 \%$ compared to $19.10 \%$ for IPOs without VC-backing. However, for both markets, the difference in (both mean and median) underpricing between VC-backed firms and other firms is not statistically significant.

We categorise VCs as domestic if they are a member of the VC association of the country in which the IPO is taking place and as international if they are a member of one or more VC associations of other countries. ${ }^{9}$ We find that for both markets the level of underpricing for those IPOs which are backed by domestic VCs is similar to that for those which are backed by international VCs. Further, there are more German IPOs with UK/US-based VCs than French ones. However, their presence does not affect the level of underpricing. Therefore, it seems that the presence of VCs and their reputation (as measured by their international character) does not influence the pricing of IPOs in the EuroNMs.

If VCs have the power to influence the pricing of IPOs, the level of underpricing will be lower if they intend to sell the majority of their shares in the IPO. We check if the selling behaviour and the post-IPO stake of the VC are related to underpricing. We find that the level of underpricing, when VCs retain most of their shares after the IPO, is similar to the level of underpricing when VCs sell most of their holdings in the IPO. This is true for both markets. The postIPO ownership held by the VCs in the German market does not seem to affect the level of underpricing. However, for those French IPOs

\footnotetext{
${ }^{9}$ For example, Gold-Zack AG is a member of the German VC association only and has been classified as a domestic VC. Advent International is not a member of the German VC association but is a member of VC associations of 6 other countries and hence is classified as an international VC. Similarly for the French market, Banque De Vizille is a member of the French VC association only and is thus considered as domestic, whereas Innovacom is an international VC as it is a member of both the French and EU VC associations.
}

where the VC holds a below-median post-IPO stake in the firm, the level of underpricing is much smaller than when the VC has an above-median ownership stake. Still, the difference (both in the mean and median) is not statistically significant.

Finally, we examine whether VCs are represented on the supervisory board and/or the management board of the firms they invest in and whether this has an impact on underpricing. Out of the 124 VC-backed German firms, there are only 30 cases (24.2\%) where at least one $\mathrm{VC}$ is a member of the supervisory board and only one firm (WEB.DE AG) where the VC is a member of the management board. For France, out of the 57 VC-backed IPOs, 34 (59.6\%) have at least one VC who is a member of the supervisory board and only three firms have at least one VC represented on the management board (but not on the supervisory board). In only one firm (InfoVista SA) is the VC a member of both the supervisory and the management board. Even though VCs are represented on the supervisory board of a quarter of the German VC-backed firms and around $60 \%$ of the French ones, underpricing in these IPOs is not statistically different from IPOs without VC board representation. However, for Germany, we still find a large economic difference in underpricing between the two types of IPOs (Table 7). This evidence should be interpreted with caution as Bessler and Kurth (2007a, 2007b) show that when VCs are affiliated with the underwriter the level of underpricing is almost twice that of IPOs where the VCs are not affiliated with the underwriter.

To summarise, VCs do not seem to have an impact on the underpricing of IPOs in either of the two EuroNM markets and therefore the validity of Hypothesis 2 that VC backing signals quality is not corroborated for the EuroNM markets.

\section{Regression analysis}

Models 1 and 2 of Table 8 explain the underpricing in the German and French EuroNM IPOs, respectively. For model 2, we only consider French IPOs after 1 December 1998 as, prior to this date, all 
Table 8

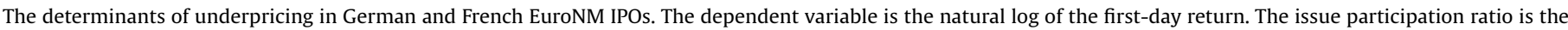

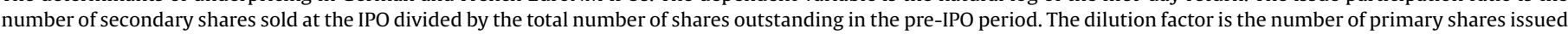

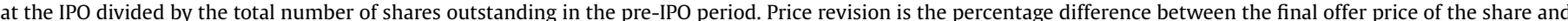

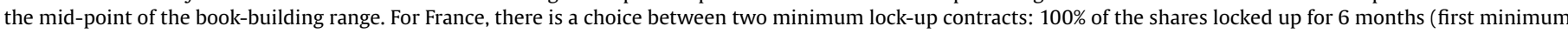

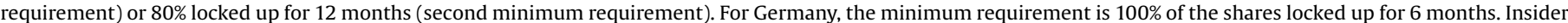

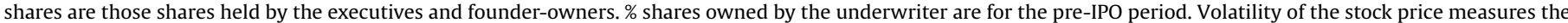

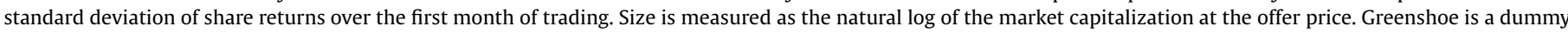

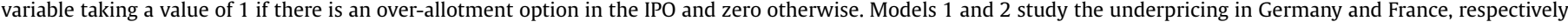

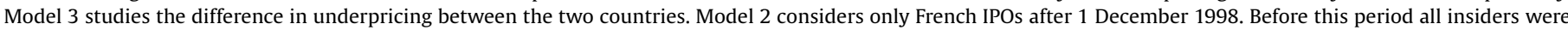
locked up for 3 years with $80 \%$ of their holdings. The figures in parentheses are the $t$-statistics.

\begin{tabular}{|c|c|c|c|}
\hline Independent variables & $\begin{array}{l}\text { Germany } \\
\text { Model (1) }\end{array}$ & $\begin{array}{l}\text { France } \\
\text { Model (2) }\end{array}$ & $\begin{array}{l}\text { Difference in underpricing } \\
\text { Model (3) }\end{array}$ \\
\hline Constant & $4.37(3.69)^{* * *}$ & $3.71(2.43)^{* *}$ & $0.036(0.17)$ \\
\hline Issue participation ratio & $-0.32(-0.66)$ & $-0.005(-0.58)$ & $0.006(0.67)$ \\
\hline Dilution factor & $0.13(0.52)$ & $0.39 \times 10^{-3}(0.07)$ & $0.016(1.57)$ \\
\hline Price revision & $3.51(6.72)^{* * *}$ & $0.040(3.61)^{* * *}$ & $0.023(2.41)^{* *}$ \\
\hline$\%$ of VC shares not locked-up & & $0.10(0.49)$ & \\
\hline$\%$ of VC shares locked-up beyond the minimum requirement & $-0.25 \times 10^{-3}(-0.19)$ & $-1.04(-3.39)^{* * *}$ & $-0.005(-1.72)^{*}$ \\
\hline$\%$ of outsider shares (except VC) locked-up for the first minimum requirement & & $-0.06(-0.32)$ & \\
\hline$\%$ of outsider shares (except VC) locked-up for the second minimum requirement & & $0.14(0.79)$ & \\
\hline$\%$ of outsider shares (except VC) locked-up beyond the minimum requirement & $0.83 \times 10^{-3}(0.62)$ & $0.75(2.06)^{* *}$ & $0.004(0.94)$ \\
\hline$\%$ of insider shares locked-up for the first minimum requirement & & $0.68(2.35)^{* *}$ & \\
\hline$\%$ of insider shares locked-up for the second minimum requirement & & $0.56(2.15)^{* *}$ & \\
\hline$\%$ of insider shares locked-up beyond the minimum requirement & $-0.68 \times 10^{-3}(-0.56)$ & $0.56(2.64)^{* *}$ & $-0.004(-0.78)$ \\
\hline$\%$ shares owned by the underwriter & $1.21(2.01)^{* *}$ & $-2.13(-2.64)^{* *}$ & $-1.27(-0.68)$ \\
\hline Volatility of stock price & $4.81(3.57)^{* * *}$ & $10.27(3.49)^{* * *}$ & $8.21(3.14)^{* * *}$ \\
\hline Size of the issuer & $-0.05(-0.78)$ & $-0.07(-0.78)$ & \\
\hline Greenshoe (over-allotment option) present & $-0.14(-1.17)$ & $0.11(0.92)$ & $-0.027(-0.15)$ \\
\hline Age of the issuer & $-0.006(-0.10)$ & $0.05(0.62)$ & $0.106(0.90)$ \\
\hline Return on market index during the quarter before the IPO (NEMAX, French NM) & $0.008(6.28)^{* * *}$ & $0.002(1.23)$ & \\
\hline Bubble (1999-2000) & $0.21(2.08)^{* *}$ & $0.08(0.57)$ & $0.272(1.78)^{*}$ \\
\hline SIC 20-39 (Manufacturing) & & $0.11(0.48)$ & \\
\hline SIC 40-49 (Transport and Public Utilities) & $-0.14(-0.62)$ & $0.30(1.33)$ & \\
\hline SIC 50-51 (Wholesale Trade) & $0.27(1.30)$ & $-0.33(-0.98)$ & \\
\hline SIC 60-67 (Fin., Insurance and Real Estate) & $-0.27(-1.11)$ & & \\
\hline SIC 70-89 (Business Services) & $-0.02(-0.20)$ & & \\
\hline Adj. $R^{2}$ & $34.70 \%$ & $43.94 \%$ & $23.11 \%$ \\
\hline Sample & 262 & 61 & 61 \\
\hline$P$-value ( $F$ statistic) & 0.00 & 0.00 & 0.01 \\
\hline
\end{tabular}

* Statistical significance at the $10 \%$ level.

** Statistical significance at the $5 \%$ level.

*** Statistical significance at the $1 \%$ level.

insiders were required to be locked up for 3 years with $80 \%$ of their holdings. Given that the Neuer Markt and the Nouveau Marché both started around the same time, were members of the same EuroNM network with similar listing rules and had a number of similar firm characteristics such as age, VC backing, lock-up agreements and the use of the book-building procedure, the large difference in underpricing between the two markets is intriguing. Model 3 attempts to explain some of the reasons for the difference in underpricing between the two countries.

Unlike the studies on US IPOs, we do not find a statistically significant relation between the changes in insider ownership and underpricing. The coefficients on the issue participation ratio and dilution factor are neither statistically significant for the German nor the French market. Thus, Habib and Ljungqvist's (2001) assertion that the insiders set the offer price to minimise their personal wealth losses in the IPO is not supported for these markets and we do not find support for Hypothesis 1. The interpretation of this result is that the insiders of French and German IPOs do not use lower underpricing as a tool to protect their personal wealth losses when selling shares at the time of the IPO. This behaviour is in stark contrast to their US counterparts.

We find that underpricing is positively related to the price revision. The higher the price revision, the higher is the level of underpricing. Hence, we find support for Benveniste and Spindt's (1989) argument that potential investors need to be compensated for revealing truthful information about the demand for the issue.
Both the German and the French underwriters only partially adjust the final offer price towards the firm value revealed by the potential investors. ${ }^{10}$ Therefore, we fail to reject Hypothesis 3.

For the German IPOs, there is no significant relation between the stringency of lock-up agreements and underpricing. Neither the length of the lock-up agreements nor the fraction of the locked up shares acts as a substitute or complement to underpricing. For France, the results are different: if VCs are locked up beyond the minimum requirements, the level of underpricing is smaller. This implies that the lock-up contracts for VCs act as a substitute device for underpricing. Further, as the stringency of the insider lock-up agreements increases (from the first legal minimum contract to the second legal minimum requirement, and then beyond the two legal minimums), the level of required underpricing decreases, which further supports the substitution hypothesis for France. ${ }^{11}$ Therefore, for the French market, there is general support for Hypothesis $4 \mathrm{~b}$.

\footnotetext{
10 For France, we also used the oversubscription levels as an alternative proxy for investor demand. Our results do not change.

11 It is somewhat puzzling that, if the outsiders (apart from the VCs) are lockedup beyond the two minimums, the level of underpricing is larger. However, there are only 9 out of the 61 firms with outsiders locked up beyond the two minimum requirements.
} 
We find that the fact that an underwriter is also a shareholder affects the level of underpricing. For German IPOs with a shareholder-underwriter, the larger the number of pre-IPO shares owned by the underwriter, the larger is the underpricing. In contrast, this relation is negative for the French IPOs. These results suggest that the German and French underwriters have conflicting views on the wealth loss caused by the underpricing and the benefits from obtaining future business. Even though the German underwriters sell a relatively higher proportion of their holdings in the IPO, ${ }^{12}$ for them underpricing is an acceptable price to pay in order to secure a higher volume of future business and a high probability of a successful issue. ${ }^{13}$ The French underwriters provide evidence of the opposite behaviour. Therefore, we obtain support for Hypothesis $5 a$ for Germany and for Hypothesis $5 b$ for France. ${ }^{14}$

When we control for the ex ante uncertainty in the IPOs, we find that the higher the volatility of the share price, the larger is the level of underpricing. The results are highly significant and valid for both markets. Therefore, riskier firms are more underpriced. Further, the size of the issuer, the existence of an over-allotment option and the age of the IPO firm do not have any impact on underpricing for both markets.

For Germany, past market movements also have an impact on the level of underpricing. The higher the market return in the quarter prior to the IPO, the higher is the underpricing. No such relationship is evident for the French IPOs. We also investigate the impact of the dot com bubble period (1999-2000) and find that for the German IPOs, the level of underpricing was higher during that period. No such relationship is evident for the French IPOs. The German evidence is in line with the findings by Loughran and Ritter (2002) who report a positive relation between underpricing and past stock market movements for the US. The results in Table 8 further show that for Germany and France underpricing is not industry specific: high-tech issues in the Business Services industry (SIC 70-89) are underpriced to a similar degree as flotations in more mature industries, such as Transport and Utilities (SIC 40-49).

Finally, model 3 estimates the determinants of the differences in the level of underpricing between the two countries. To study the reasons for the difference in underpricing between the two markets, we match the German and French firms first by industry (using two-digit SIC codes) and then by size (to the nearest $€ 1,000,000$ for small firms and $€ 5,000,000$ for large firms $)^{15}$ using the market capitalization at the offer price. We are able to match all the 61 French firms using these two criteria. The last column of Table 8 reports the results for an OLS regression with the difference in underpricing between each pair of matched German and French IPOs as the dependent variable and the difference between the explanatory variables on the right-hand side. The results show that the difference between the two markets in terms of owner-

\footnotetext{
12 The selling behaviour of the German and French underwriters was also quite different. For 30\% of the German IPOs whose underwriter was also a shareholder, the underwriter did not sell any shares, whereas in nearly half of the IPOs, the underwriter sold more than $30 \%$ and in $16 \%$ of the IPOs the underwriter sold all its shares. In contrast, for the equivalent French IPOs, in nearly half of them the underwriters did not sell any of their shares and in only $16 \%$ did the underwriter sell more than $30 \%$. There were no IPOs in which the underwriter sold all of its shares.

${ }^{13}$ We speculate that one of the reasons for the very high underpricing in the German market was that the underwriters in Germany were using heavily underpriced shares to retain and also attract new clients. This behaviour was not so prominent for the French underwriters. We are thankful to the referee for pointing this out.

14 The difference in the impact of shareholder-underwriters on underpricing is not caused by differences in the market momentum as the coefficient on the interaction term between the two variables is not significantly different from zero.

15 We define small firms as those with a market capitalisation of $€ 30$ million or less. Firms with a market capitalisation of more than $€ 30$ million are defined as large firms.
}

ship dilution (dilution factor and issue participation ratio) does not explain the large difference in underpricing. Conversely, the difference in the level of price revisions between the markets explains the difference in underpricing. From Table 2, we know that the average price revision in Germany is almost twice that in France. Table 8 confirms that the larger the difference in the price revision, the larger is the difference in underpricing.

The difference in the stringency of VC lock-up agreements in terms of their length and the percentage of shares locked up also explains part of the differences in underpricing between Germany and France. The German IPOs experience higher underpricing because a relatively smaller percentage of VC shares are locked up beyond the minimum requirement. Indeed, Goergen et al. (2006) show that only $33 \%$ of the VC shares are locked up beyond the minimum requirement in Germany compared to 60\% in France. However, the difference in the lock-up length for insiders and that for outsiders other than VCs does not explain the difference in underpricing between the two markets.

The difference in the level of pre-IPO ownership by underwriters in the two countries does not explain the large difference in underpricing between the two markets. However, the difference in ex ante uncertainty - the average volatility of the German IPOs is around $15.14 \%$ compared to only $5.00 \%$ for the French IPOs - is one of the main reasons for the difference in underpricing.

Finally, the existence of over-allotment options in most German firms (89\% of the IPOs have Greenshoe options compared to only $46 \%$ of IPOs in France) does not explain the large difference in underpricing between the two countries. Likewise, the age difference between the matched pairs of German and French firms also fails to explain the difference in underpricing. ${ }^{16}$

\subsection{Robustness check}

Bessler and Kurth (2007a, 2007b) argue that some of the IPOs that came to the Neuer Markt in 1997 were not new economy firms and were similar (in terms of age, dividend payments, etc.) to the IPO firms that went public prior to the existence of the Neuer Markt. Therefore these firms should be excluded from the studies of the Neuer Markt. However, when these firms are excluded, our regression results are qualitatively and quantitatively similar to the ones presented above. There are no changes to the model 3 regression results as the size and industry match between Germany and France did not involve any 1997 IPOs.

\section{Conclusion}

IPOs on the EuroNMs are characterised by the presence of lockup agreements, the use of the book-building procedure for their valuation, venture-capital backing, the existence of over-allotment options and high levels of underpricing. In this paper, we first document some of these idiosyncrasies and then focus on how - if at all - they influence the level of underpricing in the two largest members of EuroNM network, namely the Neuer Markt of Germany and the Nouveau Marché of France.

We find that all IPOs (except for one German IPO) use the bookbuilding procedure for their pricing. IPOs from both markets have lock-up periods which exceed the compulsory minimum. We also find that a large number of IPOs from both markets are venturecapital backed and that a large number of VCs do not sell any of their holdings in the IPO.

\footnotetext{
16 It should be noted that the sample size is only 61 for France as we exclude firms that came to the market before 1 December 1998. Indeed, in these IPOs, all insiders had to be locked up for 3 years for $80 \%$ of their holdings.
} 
We find that the high level of underpricing in both markets is neither driven by insider selling behaviour nor by the dilution of insider ownership in the IPO. We show that IPOs are highly underpriced if they are risky and if their offer price is revised upwards. Lock-up agreements seem to act as substitute devices to underpricing for the case of French IPOs. Also, for the French firms, if the VCs are locked up beyond the minimum requirement, then the underpricing is lower. Further, the more stringent the French lock-up, the smaller is the level of underpricing. The presence of underwriters as shareholders has a positive impact on underpricing in Germany but a negative one in France. This suggests that German underwriters may have been willing to suffer wealth losses resulting from underpricing in order to capture future business. In contrast, French underwriters may be more concerned about minimising their personal wealth losses due to underpricing. Finally, we explore the reasons for the large difference in underpricing between the German and French EuroNM markets and find that German firms are relatively more underpriced than French firms because they are riskier, have larger price revisions, have less stringent VC lock-up contracts and go public mostly during the hot issue period when the general level of underpricing in all IPO markets is substantially higher.

Future research on the underpricing of European stock markets should focus on extending the Rocholl (2007) and Bessler and Bittelmeyer (2008) studies on German IPOs to other markets such as France. Following Rocholl, comparisons of stock option plans for Germany and France should be made in order to document the differences in the stock options granted to insiders, in the exercise price for such stock options, and their (likely) effect on underpricing. Similarly, future studies should examine the extent of patent rights owned by IPO companies in the two markets. Finally, the behaviour of the underwriting banks that are in charge of the share allocations warrants a thorough investigation.

\section{Acknowledgements}

The authors would like to thank Wissam Abdallah, PeterPaul Angenendt and Marie-Thérèse Camilleri-Gilson for excellent research assistance. We are also grateful to the two IRLE referees, Leon Hadass, Susanne Espenlaub, Giancarlo Guidici, Jeremy Kaefer, Marianne Kaefer, Kurt Shefari, Alexander Ljungqvist, Jeanne Plym-Shapo, Peter Roosenboom, Johan Stockem, the participants at the Third Workshop on Economic Change - The Microfoundations of Institutional and Organisational Change and the 2006 annual meetings of the European Financial Management Association. We acknowledge financial support from the European Commission Key Action "Improving the socio-economic knowledge base" through contract No. HPSE-CT-2002-00146.

\section{References}

Aggarwal, R., Krigman, L., \& Womack, K. (2002). Strategic IPO underpricing, information momentum and lock-up expiration selling. Journal of Financial Economics, $66,105-137$.

Arosio, R., Giudici, G., \& Paleari, S. (2000). Why do (or did?) Internet-stock IPOs leave so much "Money on The Table"? Working paper. Italy: University of Bergamo.

Barry, C. (1994). New directions in research of venture capital finance. Financial Management, 23, 3-15.

Barry, C. B., Muscarella, C. J., Peavy, C. W., \& Vetsuypens, M. R. (1990). The role of venture capitalists in the creation of public companies: Evidence from the going public process. Journal of Financial Economics, 27, 447-471.
Benveniste, L. M., \& Spindt, P. A. (1989). How investment bankers determine the offer price and allocation of new issues. Journal of Financial Economics, 24, 343361.

Bessler, W., \& Bittelmeyer, C. (2008). Patents and the performance of technology firms: An empirical analysis of initial public offerings in Germany. Financial Markets and Portfolio Management, 32, 323-356.

Bessler, W., \& Kurth, A. (2007a). Agency problems and the performance of venturebacked IPOs in Germany: Lock-up periods, bank ownership and exit strategies. European Journal of Finance, 13, 29-63.

Bessler, W., \& Kurth, A. (2007b). Agency problems and the performance of venturebacked IPOs in Germany: Lock-up periods, bank ownership and exit strategies. European Journal of Finance, 2007, 29-63.

Bessler, W. \& Stanzel, M. (2007). Conflicts of interest and research quality of affiliated analysts: Evidence from IPO underwriting. Working paper. University of Giessen.

Brau, J., Lambson, V., \& McQueen, G. (2004). Lock-ups revisited. Journal of Financial and Quantitative Analysis, 40, 519-530.

Chahine, S. (2008). Underpricing versus gross spread: New evidence on the effect of sold shares at the time of the IPO. Journal of Multinational Financial Management $18,180-196$

Chahine, S., \& Filatotchev, I. (2008). Do venture capitalists certify and monitor new issues? Global Finance Journal, 18(3), 351-372.

Chahine, S., Filatotchev, I., \& Wright, M. (2007). Venture capitalists, business angels, and performance of entrepreneurial IPOs in the UK and France. Journal of Business Finance and Accounting, 34, 505-528.

Cockburn, I., \& Wagner, S. (2007). Patents and the survival of internet related IPOs. Working paper. LMU Munich and NBER.

Derrien, F., \& Womack, K. L. (2003). Auctions vs. bookbuilding and the control of underpricing in hot IPO markets. Review of Financial Studies, 16, 31-61.

DuCharme, L. L., Rajgopal, S., \& Sefcik, S. E. (2002). Why was internet IPO pricing so severe? Working paper. University of Washington.

Espenlaub, S., Goergen, M., \& Khurshed, A. (2001). IPO lock-up agreements in the UK. Journal of Business Finance and Accounting, 28, 1235-1278.

Franzke, S. (2004). Underpricing of venture-backed and non-venture backed IPOs: Germany's Neuer Markt. In G. Giudici \& P. Roosenboom (Eds.), The rise and fall of Europe's New Stock Markets, advances in financial economics, 10. UK: Elsevier.

Franzke, S. \& Schlag, C. (2002). Over-allotment options in IPOs on Germany's Neuer Markt-An empirical investigation. CFF working paper. Germany: Centre for Financial Studies.

Giudici, G., \& Roosenboom, P. (2004). Pricing initial public offerings on Europe's New Stock Markets. In G. Giudici \& P. Roosenboom (Eds.), The rise and fall of Europe's New Stock Markets, advances in financial economics, 10. UK: Elsevier.

Goergen, M., Khurshed, A., McCahery, J., \& Renneboog, L. (2003). The rise and fall of the European New Markets: On the short- and long-run performance of hightech initial public offerings. In J. McCahery \& L. Renneboog (Eds.), Venture capital contracting and the valuation of high technology firms. Oxford University Press.

Goergen, M., Renneboog, L., \& Khurshed, A. (2006). Explaining the diversity in shareholder lock-up agreements. Journal of Financial Intermediation, 15, 254-280.

Goergen, M., \& Renneboog, L. (2003). Why are the levels of control (So) different in German and UK companies? Evidence from initial public offerings. Journal of Law, Economics and Organization, 19(1), 141-179.

Guo, R., Lev, B., \& Chi, S. (2006). Explaining the short- and long-term IPO anomalies by R\&D. Journal of Business Finance and Accounting, 33, 550-579.

Habib, M., \& Ljungqvist, A. (2001). Underpricing and entrepreneurial wealth losses in IPOs: Theory and evidence. Review of Financial Studies, 14, 433-458.

Jain, B. A., \& Kini, O. (2000). Does the presence of venture capitalists improve the survival profile of IPO firms? Journal of Business Finance and Accounting, 27, 1139-1176.

Jenkinson, T., \& Ljungqvist, A. (2001). Going public: The theory and evidence on how companies raise equity finance (2nd Edition). Oxford University Press.

Kanji, G. (1995). 100 statistical tests. London: Sage Publications.

Ljungqvist, A. (1997). Pricing initial public offerings: Further evidence from Germany. European Economic Review, 41, 1309-1320.

Ljungqvist, A., \& Wilhelm, W. J. (2003). IPO pricing in the Dot-Com bubble. Journal of Finance, 58, 723-752.

Loughran, T., \& Ritter, J. (2004). Why has IPO underpricing changed over time? Financial Management, 33(Autumn), 5-37.

Loughran, T., \& Ritter, J. (2002). Why don't issuers get upset about leaving money on the table in IPOs? Review of Financial Studies, 15, 413-443.

Ofek, E., \& Richardson, M. (2003). DotCom Mania: The rise and fall of internet stock prices. Journal of Finance, 58, 1113-1137.

Ritter, J. (1987). The costs of going public. Journal of Financial Economics, 19, 269-282.

Ritter, J. (2003). Differences between European and American IPO Markets. European Financial Management, 9, 421-434.

Rocholl, J. (2007). The private benefits of listing. Working paper. Germany: European School of Management and Technology.

Tykvová, T., \& Walz, U. (2007). How important is participation of different VCs in German IPOs? Global Finance Journal, 17, 350-378. 